\title{
Mg-Feのメカニカルアロイングによる合成
}

\author{
小林 慶三, 尾崎 公洋, 杉山 明, 西尾 敏幸 \\ 名古屋工業技術研究所, $\bar{T} 462-8510$ 名古屋市北区平手町 1-1.
}

\section{Synthesis of Mg-Fe Alloys by Mechanical Alloying}

\author{
Keizo Kobayashi, Kimihiro Ozaki, Akira Sugiyama and Toshiyuki Nishio \\ National Industrial Research Institute of NAGOYA, 1-1 Hirate-cho Kita-ku, Nagoya 462-8510.
}

Received May 20, 1999

\begin{abstract}
SYNOPSIS
$\mathrm{Mg}-\mathrm{x}$ mass\% $\mathrm{Fe}(\mathrm{x}=0,5,10,20)$ alloys were synthesized by mechanically alloying of elementary $\mathrm{Mg}$ and $\mathrm{Fe}$ powder for $180 \mathrm{ks}$ milling under $66 \mathrm{kPa}$ argon gas atmosphere using by a planetary ball milling. The obtained MA powders were composite materials of $\mathrm{Mg}$ and $\mathrm{Fe}$, the reaction between $\mathrm{Mg}$ and Fe did not occurred during the $\mathrm{MA}$ process. After the MA process, $\mathrm{Mg}$-Fe powders not containing more than 10 mass\%Fe became disc shape and $\mathrm{Mg}$ 20 mass $\% \mathrm{Fe}$ powder became grain of $2 \mathrm{~mm}$. In the case of $\mathrm{Mg}-15 \mathrm{mass} \% \mathrm{Fe}$, the obtained $\mathrm{MA}$ powder became big blocks by the joining of the MA powders during the MA process. The Mg-15mass\%Fe MA powder was able to consolidate by pulsed current sintering at $773 \mathrm{~K}$ under a pressure of $19 \mathrm{MPa}$. It was observed that the fine and homogenius Fe particles dispersed in the sintered body. In the MA process of $\mathrm{Mg}-15$ mass $\% \mathrm{Fe}$, the bulky compact was obtained by the controlling of a milling condition.
\end{abstract}

KEY WORDS

$\mathrm{Mg}-\mathrm{Fe}$ alloy, mechanical alloying, composite, spark plasma sintering

\section{1 緒 言}

$\mathrm{Mg}$ 合金は軽量でリサイクル性に優れることから, プラス チックに代わる新しい材料として電気部品や自動車部品など の分野で注目されている.しかし，Feが混入すると耐食性が 低下することが知られており，これまで $\mathrm{Mg}$ 合金は高純度化 の方向へ進んできた. また, 溶解した Mg合金は非常に活性で あり，セラミックス粒子 ${ }^{1,2)} や$ 他の金属材料 ${ }^{3)}$ との複合化も難 しい. そのため, 溶解法を利用して Mg合金に種々の機能性を 付与する合金開発に関しては報告例が少ない。

メカニカルアロイング(以下，MAと記す) 法は固相状態で 金属粉末どうしを合金化できるため，溶融状態では混合でき ない合金系においても合金化が可能である.また，比重差の 大きな合金系においても均一な混合を行うことができる，そ こで, 本研究では, $\mathrm{Mg}$ 粉末と Fe粉末を出発原料としてMA法 により複合化することを試みた。これまでに鉄の軽量化を目 的として, Fe と Mg を MA 法で複合化する研究について報告4) したが, Fe 量の多い合金系では Fe と $\mathrm{Mg}$ が層状になった粉末
がMAにより得られた.しかし，純 MgのMAについては報告 例がとんどなく，MA法により Mg-Fe 合金を複合化した場 合, どのような粉末が得られるかは興味深いところである. MA 法で硬質なセラミックス粒子を金属中へ均質に分散させ ることは報告らされているが，Fe粉末のように展延性を有す る材料がどのように金属中へ分散するかはわからない.また， $\mathrm{Fe}$ 粉末を均一に $\mathrm{Mg}$ 中に分散することができれば軽量な磁性 材料を提案することもでき，工業的な展開もはかられる.

さらに, 得られた MA粉末をパルス通電焼結法により固化 成形することを試みた。パルス通電焼結は，試料を溶解せず に固化成形できるため, MA 粉末における $\mathrm{Mg}$ と Feの混合状 態を変化させることなくバルク化できる可能性がある.また， 黒鉛型を用いたバルス通電焼結では焼結雾囲気が還元需囲気 であるため, $\mathrm{Mg}$ の燃焼を生じることなく, 安全に成形するこ とができる．このプロセスでバルク化ができれば，圧延や鉞 造による二次成形が可能となり，この材料の用途を拡大する ことも期待できる. 


\section{2 試料調整およひ実験方法}

$\mathrm{Mg}-\mathrm{Fe}$ 合金を作製するためのMA処理は, Mg粉末 (99mass\% $\mathrm{Mg})$ と $\mathrm{Fe}$ 粉末 $(99.8 \mathrm{mass} \% \mathrm{Fe})$ を出発原料として, $180 \mathrm{ks}$ 間の処 理を行った. MA 粉末に与える $\mathrm{Fe}$ 量の影響をみるため, $\mathrm{Mg}$, Mg-5mass $\% \mathrm{Fe}, \mathrm{Mg}-10 \mathrm{mas} \% \mathrm{Fe}, \mathrm{Mg}-15$ mass $\% \mathrm{Fe}, \mathrm{Mg}-20$ mass $\% \mathrm{Fe}$ の配合を行った.

MAには伊藤製作所製の遊星型ボールミル装置 $\left(\mathrm{LA}-\mathrm{PO}_{4}\right)$ を 用い， $66 \mathrm{kPa}$ の減圧アルゴンガス雾囲気下で処理を行った. MAの容器 $(500 \mathrm{ml})$ およびボール $(10 \mathrm{~mm} \phi)$ にはクロム鋼製のも のを用い, 粉末重量がボール重量の $10 \%$ になるようにした. なお，本合金の MAにはエタノールなどの焼き付き防止剤は 使用していない.これは, 焼き付き防止剤が分解して炭素源 になる可能性があり, MA 粉末の発火をもたらす危険性が高 いためである．本合金系においては，クロム鋼製の容器や ボールを使うことにより, 焼き付き現象はほとんと認められ なかった。

$\mathrm{Fe}$ 粉末はあらかじめ同じ MA 条件により 180ks 間のメカニ カルグライティング(以下, MG と記す)処理を行い, 粉末を 微細化した. 得られた粉末は目視による外観観察, 光学䫓微 鏡による組織観察, X線回折による構成相の同定を行った.

さらに,このMA粉末をパルス通電焼結機(住友石炭鉱業製 SPS-510L)により固化成形を行った. 焼結温度が773Kで，加 圧力 $19 \mathrm{MPa} に て 0.3 \mathrm{ks}$ 間保持することにより成形を行った。 $19 \mathrm{MPa}$ の成形圧力は, 一般のパルス通電焼結時の成形圧力よ りかなり低圧力である。

これは, 本MA粉末を大きな加圧力で成形すると $\mathrm{Mg}$ が成形 パンチとダイスの間に入り込み，黒鉛型を破壊するためであ る. なお，焼結温度は黒鉛型内に $3 \mathrm{~mm}$ 挿入したシース $\mathrm{K}$ 型熱 電対により直接測定した. 得られた成形体は組織観察や構成 相の同定, 磁気的特性の評価を行った. 本パルス通電焼結に おいては, 予備実験から試料温度か測定した黒鉛型温度より $10 \%$ 程度高温であることがわかっている．用いた黒鉛型は内

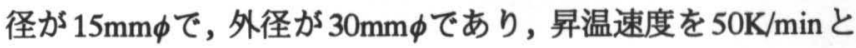
している.

\section{3 実験結果および考察}

3.1 MA合成した $\mathrm{Mg}-\mathrm{Fe}$ 合金粉末

得られた粉末の外観写真を Fig.1に示す. $\mathrm{Mg}, \mathrm{Mg}-5$ mass\% $\% \mathrm{Fe}$ および $\mathrm{Mg}$-10mass\% Fe 粉末では, Fig.1(a)に示すように $10 \mathrm{~mm} \phi$ $\times 1 \mathrm{~mm}$ 程度のディスク状の粉末が得られた.これは, $\mathrm{Mg}$ が軟 らかく耐くほみ性に優れるため, 粉砕されずに変形したため と考えられる。

また, MA粉末を詳細に観察してみると, $3 \mathrm{~mm} \phi$ 程度の細か いティスク状の粉末が集まって1つのティスクを形成してい ることがわかる.

MA粉末中の $\mathrm{Fe}$ 量が増加して 15 mass\% $\%$ とe となると, 大きな ティスク状の粉末が接合されはじめる(Fig.1(b)). これは, Fe 粉末が $\mathrm{Mg}$ 粉末のつなきとなり, MA中に粉末を接合したもの と推察される. Fe 量が増加して20mass\%Feになると, Fig.1(c)
のように粉末間の接合が阻害され, $2 \mathrm{~mm} \phi$ 程度の粒状の粉末 を形成する.これは, $\mathrm{Fe}$ 量が多くなると, MA中のボールの 衝突力によって, MA 粉末が $\mathrm{Fe}$ 粉末の多い部分で粉砕される ためと考えられる.

$\mathrm{Mg}$ 中には Feが0.001mass\%以下しか固溶しないことのから， $\mathrm{Mg}-\mathrm{Fe}$ の MA粉末はいずれの組成においても $\mathrm{Mg}$ 中に $\mathrm{Fe}$ 粉末 が分散した状態であるものと考えられる. Mgだけを MAする と, 本実験条件ではティスク状の粉末を生成した。この MA 粉末の形状的特徵はFeが10mass\%まで添加されても変化する ことはなかった. しかし, $15 \mathrm{mass} \% \mathrm{Fe}$ の添加によって複合材 料としての特性があらわれ, ティスク形状の MA粉末間の接 合が生じ, MA 粉末は大きなバルク体を形成するものと考え られる. さらに, $\mathrm{Fe}$ 量が増加すると MA粉末は粉砕されなが
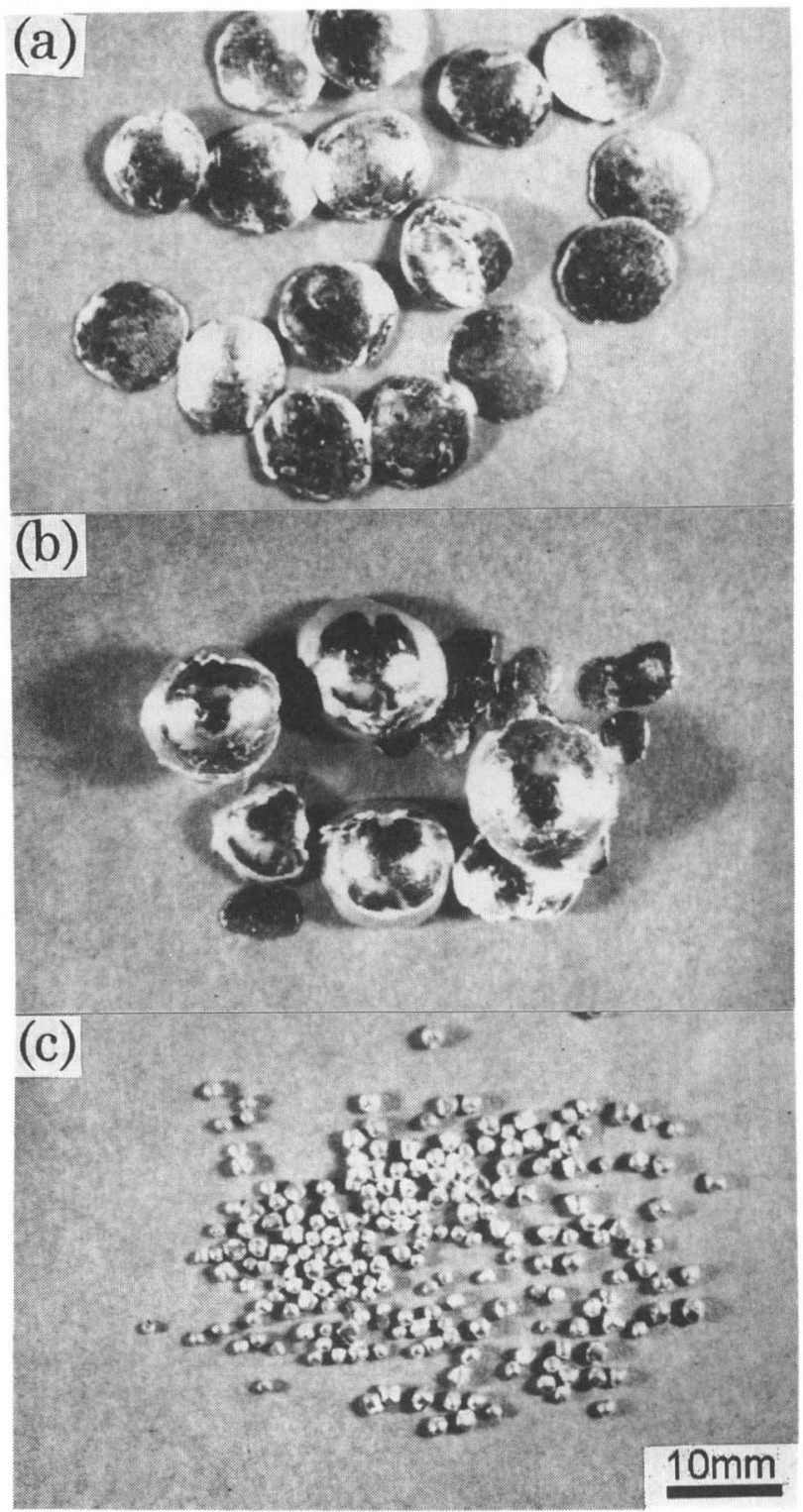

Fig.1 Appearance photography of mechanically alloyed $\mathrm{Mg}-\mathrm{Fe}$ powders milling for $180 \mathrm{ks}$. (a) $\mathrm{Mg}, \mathrm{Mg}-5$ mass $\% \mathrm{Fe}$ and $\mathrm{Mg}$ $10 \mathrm{mass} \% \mathrm{Fe}$ (these powders are same shape), (b) $\mathrm{Mg}-15$ mass $\% \mathrm{Fe}$ and (c) $\mathrm{Mg}-20$ mass $\% \mathrm{Fe}$. 
ら，造粒されて粒状の粉末になるものと考えられる。

MA で得られた各 $\mathrm{Mg}-\mathrm{Fe}$ 粉末における回折角度が $40^{\circ} \sim 60^{\circ}$ のX線回折パターンを Fig.2 に示す. 添加した Fe 量の増加 にしたがい, $\mathrm{Fe}$ のピークの高さが大きくなっている. また, いずれの Feのピークもその幅が広くなっている.これは, Fe 粉末をあらかじめMG 処理しているため, その結晶サイスが 小さくなっているためと考えられる.

$\mathrm{Mg}-15 \mathrm{mass} \% \mathrm{Fe}$ 組成の MA粉末における $20^{\circ} \sim 90^{\circ}$ の X 線回 折パターンを Fig.3に示す. 通常のマグネシウムのX線回折パ ターンクと比較して, $\mathrm{Mg}$ の(101)面の回折強度が低下し, (002) 面の回折強度が增加している.これは, $\mathrm{Mg}$ を圧延した場合に も観察されるものであり, MA 粉末がミリングんに連続的に 圧延されたことを示している. また，いずれの組成の MA 粉 末においても $\mathrm{Mg}$ のピーク位置には変化が認められないこと から, MAによる $\mathrm{Fe} の \mathrm{Mg}$ 中への固溶はほとんどないものと 考えられる。

Mg-15mass\%FeのMA粉末の断面における組織のSEM 観察 結果を Fig.4に示す. Fe粉末は $10 \mu \mathrm{m}$ 以下の微細粒子となって いる. Fig.2のX線回折結果から考えると, この Fe粒子は単一 の結晶ではなく，微細な粒子が凝集しているものと考えられ る. Fe 粒子の分散状態は良好であるが, $\mathrm{Mg}$ 量が多い本合金組 成ではFe粒子のMA中における粉砕はほとんど進行しなかっ たものと推察される.

$\mathrm{Fe}$ 粒子をさらに微細化するためには, $\mathrm{Fe}$ 粉末を少量の $\mathrm{Mg}$ とミリングすることが効果的であると考えられる.これまで に $\mathrm{Fe}$ 粉末を MG する際に $5 \mathrm{mass} \% \mathrm{Mg}$ を添加すると, $\mathrm{Fe}$ と $\mathrm{Mg}$ がサブミクロン間隔で層状に並んだ粉末年末゙得られることを

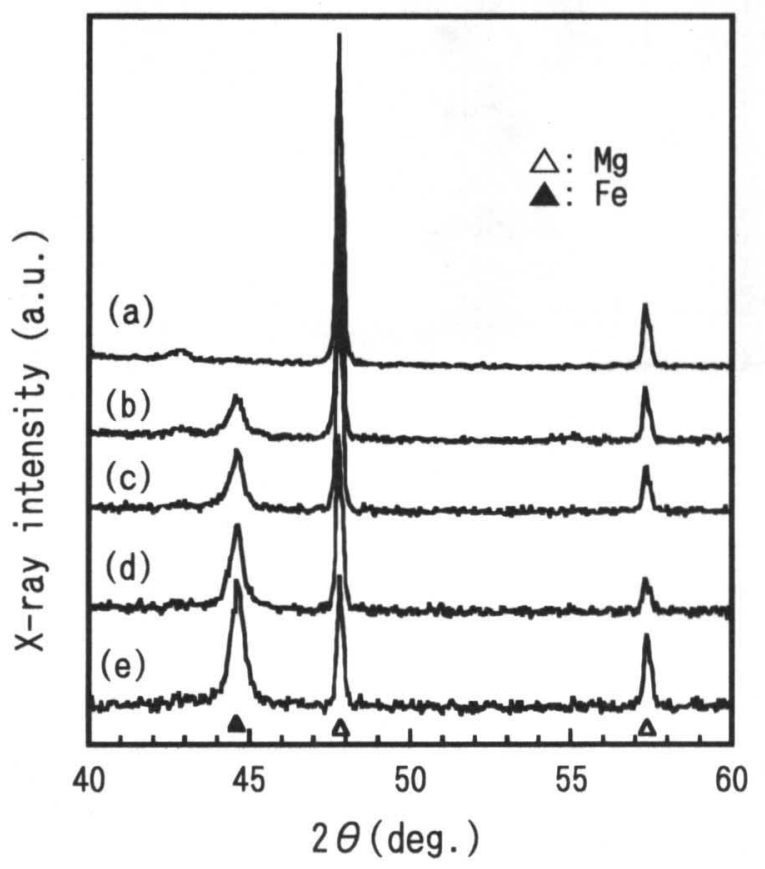

Fig.2 X-ray diffraction patterns of mechanically alloyed $\mathrm{Mg}-\mathrm{Fe}$ powders milling for $180 \mathrm{ks}$. (a) $\mathrm{Mg}$, (b) $\mathrm{Mg}-5$ mass\% $\%$, (c) Mg- 10 mass\%Fe, (d) Mg-15mass\%Fe and (e) Mg-20mass\% Fe.
報告した.この粉末を用いて同じように $\mathrm{Mg}-15 \mathrm{mass} \% \mathrm{Fe}$ 組成 の粉末を MA 合成すると, サブミクロンの Fe が分散した粉末 が得られたが, 非常に腐食されやすいため組織の観察が困難 であった. Fe-5mass\% Mgのミリングでは, $\mathrm{Fe}$ と Mg がサフミ クロンの層状構造粉末を形成し, その界面においては一部の $\mathrm{Fe}$ が Mg 中に固溶して, 耐食性を著しく損なったものと推察 される. なお, いずれの合金組成においても, MA粉末と容器 あるいはボールとの強固な反応はほとんどなく, 配合重量の 85\%以上の粉末を回収することができた.

$3.2 \mathrm{Mg}-\mathrm{Fe}$ 合金の固化成形

MAで得られた $\mathrm{Mg}-\mathrm{Fe}$ 合金を773Kでパルス通電焼結を行っ た. $\mathrm{Mg}-\mathrm{Fe}$ 合金は $\mathrm{Mg}$ が溶解 $(923 \mathrm{~K})$ すると，その比重差のた めに容易に分離し, 複合化することができない. そこで, $\mathrm{Mg}$ が溶解しない低温で加圧しながら固化成形を行った. 成形荷

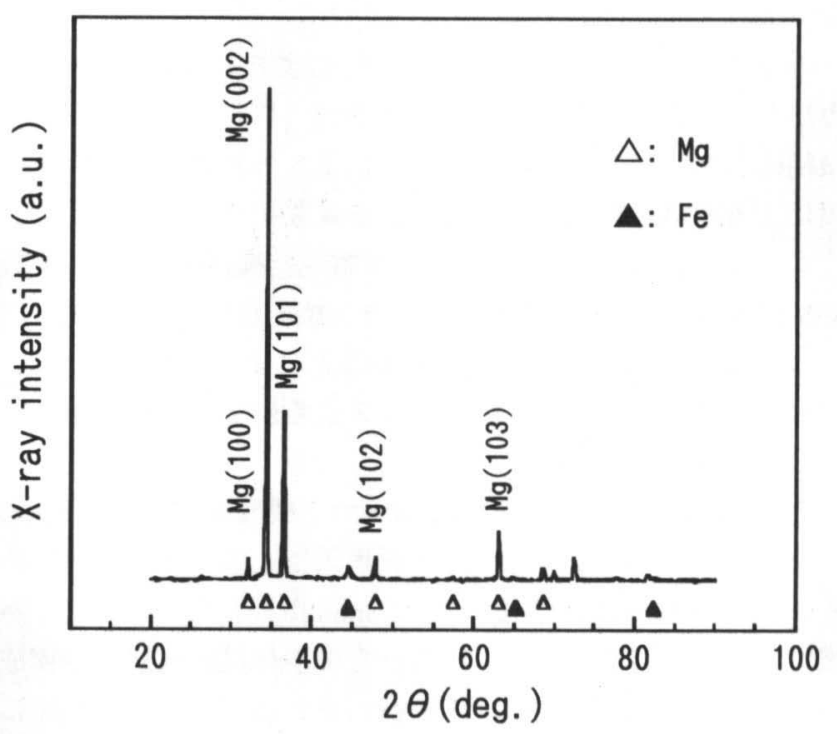

Fig.3 X-ray diffraction pattern of mechanically alloyed $\mathrm{Mg}$ 15 mass $\% \mathrm{Fe}$ powder milling for $180 \mathrm{ks}$.

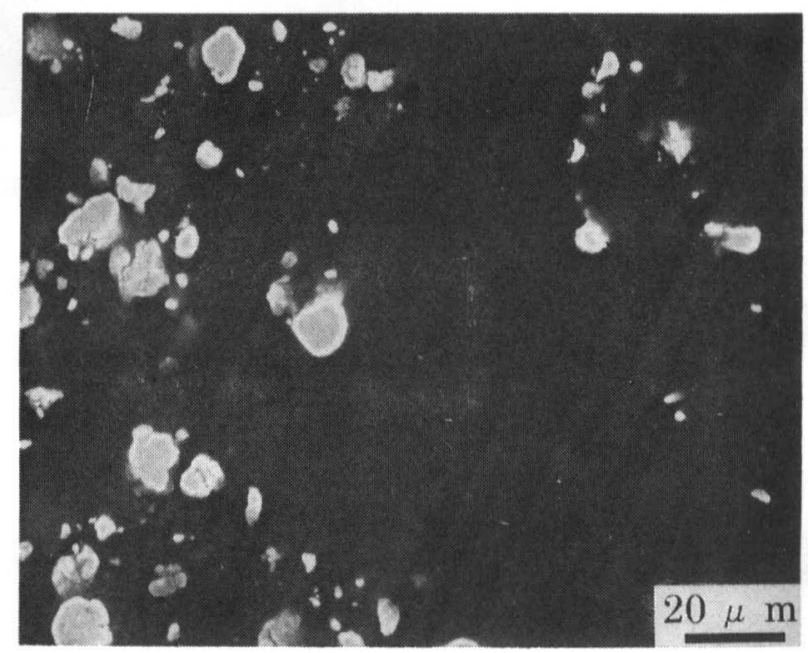

Fig.4 SEM image of mechanically alloyed $\mathrm{Mg}-15$ mass $\% \mathrm{Fe}$ powder milling for $180 \mathrm{ks}$. 
重は19MPa であり，一般のパルス通電焼結の加圧力よりかな り小さい. パルス通電焼結で成形した $\mathrm{Mg}-\mathrm{Fe}$ 合金の密度をア ルキメデス法により測定した結果を Fig.5に示す.グラフの傾 きが, $\mathrm{Mg}$ と $\mathrm{Fe}$ の混合体から計算される密度の傾きと同じで あることから，この成形体には $\mathrm{Mg}$ と $\mathrm{Fe}$ の化合物あるいは固 溶体が生成していないことがわかる. また, $\mathrm{Mg}$ のみ成形体 の密度が理論密度の $99 \%$ 以上であることから, 本成形条件は $\mathrm{Mg}-\mathrm{Fe}$ 合金の成形条件として十分であることが確認できた.

10 mass\% 以上の $\mathrm{Fe}$ を含有する合金は，焼結しても磁石(ア ルニコ磁石)についた. 得られた $\mathrm{Mg}-15 \mathrm{mass} \% \mathrm{Fe}$ 烵結体の光学 顕微鏡組織を Fig.6に示す. 焼結後も Fe 粉末の粒径は 10 $20 \mu \mathrm{m}$ 程度であり，焼結による $\mathrm{Fe}$ 粒子の粒成長はほとんど認 められなかった.これも, Feが MAによって $\mathrm{Mg}$ 中にほとん ど固溶しなかったためと考えられる. 得られた Mg-15mass\% Fe焼結体をフラックスメー夕法によりその保磁力を測定した が, 正確な值の測定は難しく, おそらく数 $\mathrm{Oe}$ 程度の保磁力を 有するものと推察された.

$\mathrm{Mg}-15 \mathrm{mass} \% \mathrm{Fe}$ 組成では MA 中に粉末が接合し，時として 大きなバルク体を形成することがあった.そこで, MA条件を 制御することによりさらに大きなバルク体の作製を試みた. Fig.1(b)ではMAボール表面を利用してバルク体が形成されて おり,ボールを包み込む形で粉末の接合が生じている.MA容 器の内面を利用してこの現象を発現させれば, より大きなバ ルク体を作製することができるものと考えられる，そこで， MAの処理量を変えてMAを行った.すすわち, 配合重量を ボール重量の7\%にして, $\mathrm{Mg}$ - 15 mass\% Fe合金をMA合成した. 投入した粉末はほとんと容器の内面に付着しており, 粉末は 強固に接合していた. 容器と MA 粉末との間での化学的な結 合は生じていないため, このバルク体は容易にはずすことが できる. 得られた MAバルク体をハンマーにて平板状にのば したものの外観写真を Fig.7 に示す. 容器の内径はおよそ

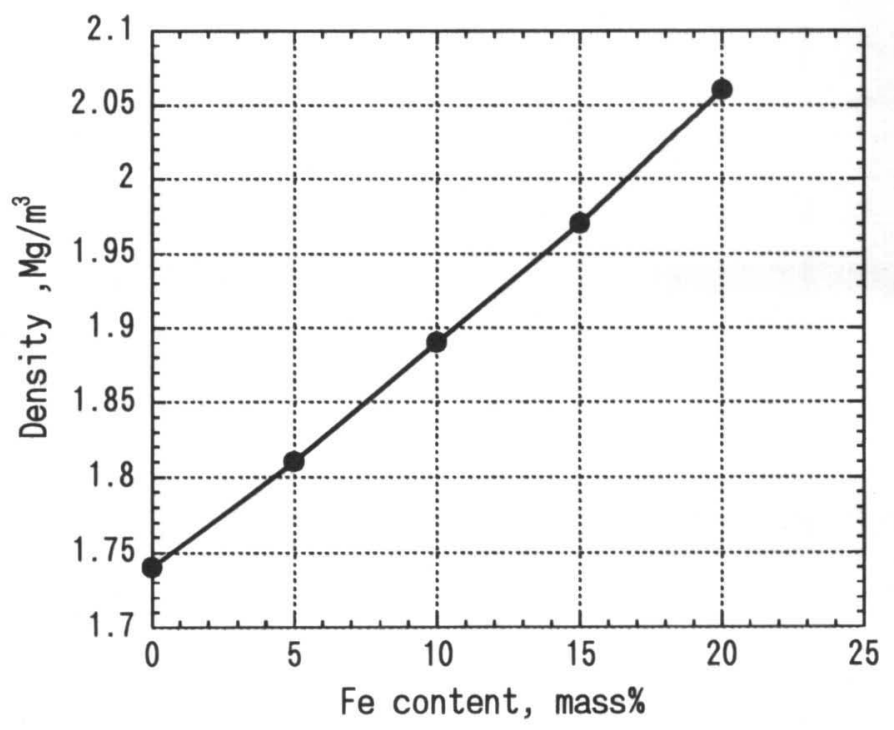

Fig.5 Density of pulsed current sintered $\mathrm{Mg}$ - $\mathrm{Fe}$ as a function of $\mathrm{Fe}$ content. 200mmであるが, この MAバルク体はハンマーで変形させて も割れを生じることがなかった. バルク体の表面は鱗状であ り, Fig.1(a)で示したディスク状の粉末がさらに圧着・接合さ れている様子がわかる.

得られた MAバルク体は厚みが $3 \mathrm{~mm}$ 程度であり, 容器との 接触面は平滑であった.このバルク体の表面を研磨しても大 きな気孔などは観察されず, 緻密なバルク体となっていた. MA 時に導入された機械的なエネルギーによって, 压延と接 合が繰り返された結果, このようなバルク体が形成されたも のと考えられる. 得られたバルク体は $\mathrm{Fe}$ 粒子が均一に $\mathrm{Mg}$ マ トリックス中に分散しており, パルス通電焼結で固化成形し た焼結体と同様にアルニコ磁石にくっついた.このバルク体 は機械的なエネルギーによって室温付近で作製されているた め, MA粉末なみの微細分散複合材料である.このプロセスは 材料に依存する部分が大きいが, MA 法によるバルク体作製 の新しい手法と考えることができる.

$\mathrm{Fe}$ が混入した $\mathrm{Mg}$ 合金は耐食性に問題があることが知られ ている.しかし，これは溶解法で作製した場合であり，本実 験のように粉末冶金法で作製した Mg-Fe合金では大きな耐食

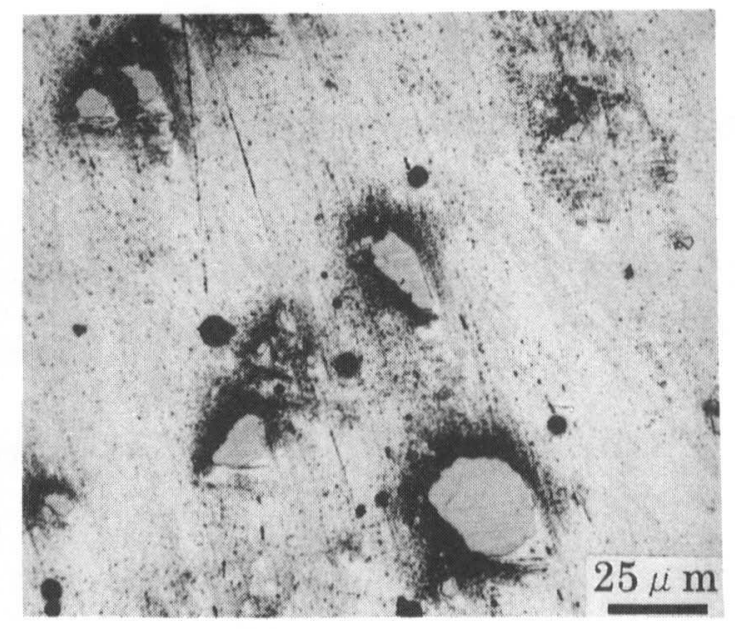

Fig.6 Microstructure of pulsed current sintered $\mathrm{Mg}-15$ mass\% $\%$ at $773 \mathrm{~K}$ under $19 \mathrm{MPa}$.

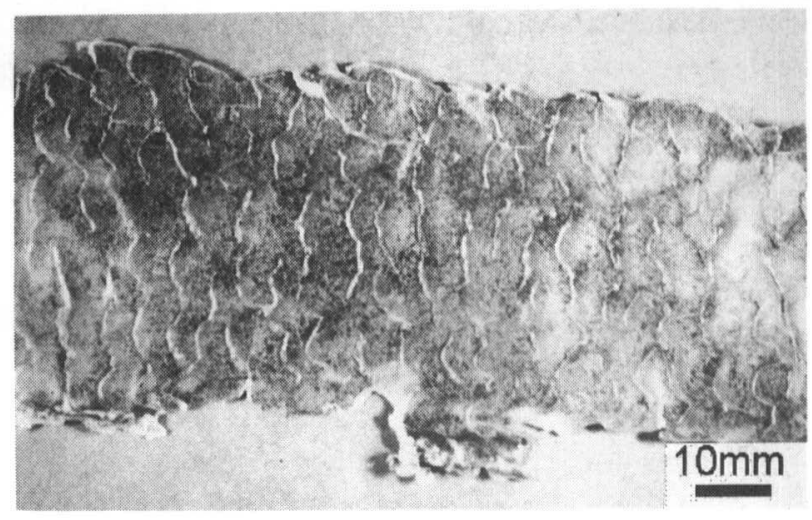

Fig.7 Appearance photography of bulky Mg-15mass\%Fe after mechanical alloying for $180 \mathrm{ks}$. 
性の低下は認められなかった。これは， $\mathrm{Mg}$ を主成分とする $\mathrm{Mg}-\mathrm{Fe}$ 合金の MAでは Fe粒子の粉砕が認められず，導入され た機械的エネルギーは $\mathrm{Mg}$ の変形に吸収されているためと考 えられる。 その結果，MAによる $\mathrm{Fe} の \mathrm{Mg}$ 中への固溶はほと んど生じず, $\mathrm{Mg}$ の耐食性が大きく変化しないものと推定され る.また，マトリックスである MgはMAの機械的なエネル ギーにより圧延と同じ効果を受けており，結晶の異方性によ り耐食性がわずかに改善されているものと推察される.

\section{4 ま と め}

$\mathrm{Mg}$ 粉末と $\mathrm{Fe}$ 粉末を出発原料として MA処理により $\mathrm{Mg}-\mathrm{Fe}$ 合金を合成した。さらに得られた MA粉末をパルス通電焼結 による固化成形を試みた. その結果，以下の結論が得られた。

(1) $\mathrm{Mg}$ 粉末と Fe粉末を出発原料として MA法で合成した $\mathrm{Mg}$ $\mathrm{Fe}$ 合金は, $\mathrm{Fe}$ 量により得られる粉末の形状か変化する. $\mathrm{Mg}-20 \mathrm{mass} \% \mathrm{Fe}$ では粉末が $2 \mathrm{~mm} \phi$ 程度の粒状となり, $\mathrm{Mg}$ $10 \mathrm{mass} \% \mathrm{Fe}$ 以下ではティスク状の粉末となる．Mg-15 mass\% Fe では MA 中にバルク体が形成される。

(2) $10 \mathrm{mass} \%$ 以上 $\mathrm{Fe}$ を含有する $\mathrm{Mg}-\mathrm{Fe}$ 粉末をパルス通電焼結 法により固化成形すると,アルニコ磁石につく複合材料を 合成できる。特に, $\mathrm{Mg}-15$ mass\% Fe 組成の焼結体は密度が $2.0 \mathrm{~g} / \mathrm{cm}^{3}$ 以下の軽量材料である.

(3) MA法とパルス通電焼結法を組み合わせたプロセスで作製
した Mg-Fe 合金は，溶解法で作製した $\mathrm{Mg}-\mathrm{Fe}$ 合金と異な り，耐食性の大きな低下は認められない。これは, 本プロ セスが室温で進行するため $\mathrm{Mg}$ 中の Fe がほとんど固溶し ないことと，MA 中に Mg が圧延されて結晶に異方性が発 現したことによるものと考えられる。

\section{文献}

1）金埃洙,金子純一, 管又信: "SiCウィスカー/AZ91 マグ ネシウム合金およびSiCウィスカー/2324アルミニウム合 金複合材料の高温変形挙動", 日本金属学会, 56(1992)819827.

2) K.Wu, M.Zheng, M.Zhao and C.Yao: "Interfacial Reaction in Squeeze Cast SiCw/AZ91 Magnesium Alloy Composite", Scripta Materialia, 35(1996)529-534.

3）西尾敏幸, 小林慶三,杉山明,尾崎公洋: "AZ91D マグネ シウム合金粉末と純金属粉末を湿合したMMC材の半溶融 組織 ", 日本鉡造工学会第 132 回全国講演大会概要集.

4）尾崎公洋, 小林慶三, 西尾敏幸: "メカニカルアロイングに よる Fe-Mg合金の作製とパルス通電焼結による固化成形", 名古屋工業技術研究所報告, 45(19)631-638.

5) J.S.Benjamin: Metal. Trans., 1(1970)243.

6) A.A.Nayeb-Hashemi, J.B.Clark and I.J.Swartzendruber: "Phase Diagram of Binary Magnesium Alloys", ASM, (1988). 